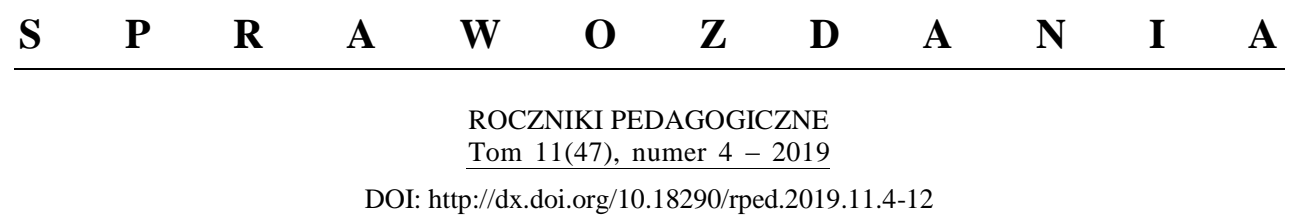

KS. DARIUSZ KONOPKO

Instytut Pedagogiki KUL

e-mail: darekkonopko@o2.pl

\title{
SPRAWOZDANIE Z POSIEDZENIA ZESPOŁU PEDAGOGIKI CHRZEŚCIJAŃSKIEJ DZIAŁAJĄCEGO POD PATRONATEM KOMITETU NAUK PEDAGOGICZNYCH PAN
}

W siedzibie Instytutu Pedagogiki Katolickiego Uniwersytetu Lubelskiego Jana Pawła II, 5 czerwca 2019 roku odbyło się posiedzenie Zespołu Pedagogiki Chrześcijańskiej działającego pod Patronatem Komitetu Nauk Pedagogicznych PAN. W programie przewidziana została Msza św. poprzedzająca obrady. Po niej rozpoczęło się spotkanie poświęcone tematowi: „Dobre praktyki” i doświadczenia integralnego wychowania do pracy.

Wszystkich uczestników przywitał i wprowadził w tematykę ks. prof. dr hab. Marian Nowak, Przewodniczący ZPCh. Ks. Profesor przekazał zebranym decyzję Centralnej Komisji do Spraw Stopni i Tytułów, która uchwałą z dnia 29 kwietnia 2019 r. przyznała Wydziałowi Nauk Społecznych Katolickiego Uniwersytetu Lubelskiego Jana Pawła II uprawnienia do nadawania stopnia doktora habilitowanego nauk społecznych w dyscyplinie pedagogika.

Po krótkim wprowadzeniu w tematykę spotkania, głos zabrał ks. prof. dr hab. Janusz Mariański (KUL, WSNS, Lublin), który wygłosił referat na temat: Praca ludzka a godność człowieka. W swoim wystąpieniu ks. Profesor zwrócił uwagę, że godność jest wartością najwyższą i bezwzględną i nie może być nigdy traktowana jako środek do celu. Człowiek zachowuje prymat w życiu społecznym i jest najważniejszą istotą wśród stworzeń. Rozwój człowieka jest priorytetem. Gospodarka musi być dostosowana do człowieka. Nie ma zysków kosztem człowieka. Kościół apeluje by była chroniona podmiotowość człowieka i poszanowane jego prawa. W świecie rządzonym przez pieniądz zauważa się dystans w stosunku do człowieka. Zbędne wydają się być nie tylko rzeczy, ale i pewne wartości.

Ksiądz Profesor zaznaczył, że godność przysługuje każdemu człowiekowi w jednakowym stopniu. Nikt nie może jej odebrać ani z niej zrezygnować. Między godnością wrodzoną i nabytą zauważa się różnice, ale stanowią one integralną całość. Godność obejmuje sferę cielesną i duchową. Prelegent zaznaczył, że praca ludzka jest wartością wielowymiarową, wskazując na jej: wartość antropologiczną; jest obowiązkiem człowieka i ma 
wartość wychowawczą; jest wartością społeczną w wymiarze rodzinnym i narodowym; jest wartością kulturową; jest wartością gospodarczą; stanowi wartość religijną - przez pracę człowiek spełnia wolę Stwórcy.

Ks. J. Mariański podkreślił, że w katolickiej nauce społecznej mówi się o godnym przeżywaniu życia. Potrzebna jest praca i odpowiednie warunki do pracy. Kościół opowiada się za integralnością pracy. Praca jest dla człowieka a nie człowiek dla pracy. Człowiek jest dziedzicem dorobku pokoleń i posiada prawa i obowiązki. Zmieniają się formy pracy, ale zostaje etos pracy.

Następnie głos zabrał prof. dr hab. Andrzej Sowiński (PWSZ im. Jakuba z Paradyża w Gorzowie Wielkopolskim) i wygłosił referat na temat: Moralne i metodyczne walory pracy jako formy wychowania. Prelegent starał się nakreślić w swoim wystąpieniu znaczenie pracy, która jest bardzo ważnym elementem wychowania. Przywołał wypowiedź Jana Pawła II, który wskazywał na szczególny rodzaj aktywności człowieka, jaką jest praca i podkreślał jej rolę. Praca wynika z natury człowieka. Wychowanie do pracy powinno respektować integralną wartość osoby. Podmiot pracy sprawuje kontrolę poznawczą nad swoimi czynnościami oraz kontrolę sprawczą, a więc ma zdolność odbierania i syntetyzowania informacji, rozumienia ich znaczenia, posiada także zdolność modyfikowania i skutecznego wywierania wpływu na zdarzenia i stan rzeczywistości. Ponadto praca i jej składowe czynności wypływają, i są zgodne z własnymi wartościami i standardami podmiotu.

Profesor przypomniał, że doświadczenie wychowanka ma charakter doznań, przeżyć nabywanych indywidualnie $\mathrm{w}$ toku swego życia, które wynosi on $\mathrm{z}$ własnych działan, zdarzeń, kontaktów i sytuacji, w których uczestniczy. Praca pojawia się w wychowaniu w dwu perspektywach: a) w perspektywie aktywności wychowanka - jako forma wychowania oraz b) w perspektywie wychowawcy - jako forma pracy wychowawczej.

Formą wychowania jest więc rodzaj aktywności wychowanka (wychowanie przez działalność artystyczną, sportową, gospodarczą i in.), jaką wychowanek przejawia w sytuacjach wychowania. Forma pracy wychowawczej jest celowo zorganizowanym układem czynności wychowawcy i wychowanków, zmierzającym do stworzenia sprzyjających warunków (okoliczności, zadań, sytuacji) dla wywołania i przejawiania pożądanych zachowań uczestników, co pozwoli osiągnąć zamierzony cel rzeczowy całego przedsięwzięcia. W toku realizacji celu rzeczowego zaistnieją ponadto korzystne warunki realizacji także funkcji osobotwórczej danej formy, zamierzonej ze względu na przyjęty cel wychowania.

Ostatnim, który w tej części posiedzenia wygłosił referat, był o. dr Janusz Mółka SJ (Akademia Ignatianum, Kraków), prezentując temat: Wartość pracy w integralnym rozwoju osoby ludzkiej. Wystąpienie Prelegent rozpoczął od przedstawienia czym jest integralne wychowanie. Fenomen osoby należy postrzegać w podwójnym świetle: rozumu i Objawienia Bożego. Doświadczenie egzystencjalne idzie w parze z doświadczeniem religijnym w potwierdzaniu prawdy, że człowiek jest osobą, czyli bytem transcendentnym, świadomym siebie i realizującym się w relacji. Za Jerzym Bagrowiczem powtórzył, że wychowanie integralne „rozumieć będziemy jako wieloaspektowe zabiegi wychowawcze, których celem jest nadanie procesom wychowania rangi działań wspomagających rozwój osoby po to, by była ona w stanie osiągnąc możliwie wysoki stopień dojrzałości". Integralne wychowanie jest rozwojem wszystkich sfer człowieka bez pomijania jakiejkol- 
wiek lub umniejszania którejś ze sfer. Zaprezentowane zostały także priorytety edukacji katolickiej, które ukazuje kard. Zenon Grocholewski, - ich istotą jest integralne wychowanie poprzez formację ludzką, duchową i intelektualną dążącą do przygotowania zawodowego (wiedza i umiejętności). Przybliżając tematykę integralnego wychowania, Ojciec Mółka zaprezentował książkę Heleny Słotwińskiej Wychowanie chrześcijańskie szansa integralnego rozwoju człowieka.

Wskazując następnie na wartość pracy, zwrócił uwagę na relacje etyki i pracy w ujęciu Józefa Lipca. Wprowadzenie etyki na teren pracy poszerzyło listę wartości i wzorców moralnych; wartości związane z pracą mają wpływ na zmianę treści pojęcia „dobro”, a także zmieniają się wyznaczniki wartości wzorcowych: „sprawiedliwość”, „własność”, „odpowiedzialność”, „,wolność”, „ofiarność”, „pomoc bliźniemu” i inne; sfera pracy wyzwala etyczne relacje: człowiek-rzecz-człowiek, w których rzeczą jest przedmiot pracy ludzkiej; etyka wzbogacana o problematykę pracy staje się dyscypliną uniwersalistyczną. Oparcie problematyki wartościowania pracy na założeniach aksjologicznych umożliwia wykorzystanie refleksji aksjologicznej w wychowaniu przez pracę, do pracy, dla pracy, w pracy.

Kończąc swoje wystąpienie, jako przykład „dobrej praktyki” integralnego wychowania, Ojciec przytoczył autobiografię Wiesława Nowaka, przedsiębiorcy i założyciela firmy „Novmar”, w której opisuje swoje rozumienie pracy jako wartości.

Po zakończonym referacie miała miejsce przerwa w posiedzeniu Zespołu. Po niej rozpoczęła się druga część obrad, która dotyczyła dobrych praktyk i świadectw oraz problemów wychowania do pracy.

Jako pierwszy zabrał głos o. dr Jarosław Charchuła SJ (Akademia Ignatianum, Kraków) prezentując temat: Wychowanie „,przez” $i$ „,do” pracy-dobre praktyki stosowane $w$ Schronisku dla Nieletnich $i$ Zakładzie Poprawczym $w$ Warszawie-Falenicy. Początkowo przedstawił specyfikę miejsca, jakim jest Schronisko dla Nieletnich i Zakład Poprawczy w Warszawie-Falenicy. Ośrodek powstał w 1959 roku i przebywają w nim dziewczęta w wieku od 13 do 21 lat. Jest to ośrodek zamknięty dla 120 osób, które mają wyroki sądowe lub są w trakcie procesów sądowych. Przy Ośrodku znajduje się Szkoła Podstawowa nr 235 i Gimnazjum nr 7, które prowadzą zajęcia dydaktyczne i przysposobienie do pracy, jak również Szkoła Branżowa I Stopnia nr 68, kształcąca uczniów w zawodach: fryzjer, kucharz i krawiec. W szkole prowadzone są także certyfikowane kursy zawodowe, m.in.: obsługa komputera, kosmetyczka, florystka, carving i inne. Najważniejsze założenia programowe dotyczą między innymi ukończenia stosownego etapu edukacji, zdobycia kwalifikacji zawodowych, zapewnienia wieloaspektowej opieki, która ma przyczynić się do pokonania zachowań antyspołecznych, wdrożenia do samodzielności w organizacji życia, pełnienia różnorodnych obowiązków oraz przygotowania do powrotu do środowiska rodzinnego i społecznego.

Ojciec Charchuła prezentował także rodzaje podejmowanych działań w Schronisku. Szczególnie podkreślał zaangażowanie wychowanek we współpracę z instytucjami zewnętrznymi, takimi jak Domy Pomocy Społecznej. Na koniec przytoczył wypowiedzi podopiecznych Ośrodka dotyczących ich pobytu w Schronisku, który przyczynił się do zmiany ich postaw i wpłynął pozytywnie na ich zachowanie.

Następnie głos zabrał dr Miłosz Mółka (Akademia Ignatianum Kraków) prezentując zagadnienie: Wolontariat przyktadem ,,dobrych praktyk” w resocjalizacji. Początkowo Prelegent ukazał obecność idei wychowania przez pracę w resocjalizacji na świecie i w Pol- 
sce. Przedstawił także podstawy prawne, które regulują możliwość wykonywania pracy przez skazanych. Zaprezentował podział zatrudnienia skazanych ze względu na dwa kryteria: miejsca i odpłatności za pracę. Biorąc pod uwagę miejsce, osadzeni mogą pracować wewnątrz zakładu karnego bądź poza nim. Natomiast kryterium odpłatności dotyczy pracy odpłatnej i nieodpłatnej, do której zalicza się wolontariat. Wskazana została także funkcja pracy jako narzędzia społecznej inkluzji osób pozbawionych wolności. Jest to: źródło dochodów; alternatywa przed monotonią; neutralizacja procesu demoralizacji, ograniczenie ryzyka (auto)agresji; szansa naprawienia szkody; sprzyjanie destygmatyzacji; kształtowanie tożsamości; uczenie zdyscyplinowania i systematyczności. Na koniec Prelegent zaprezentował formy wolontariatu w Zakładzie Karnym w Nowym Wiśniczu.

Jako ostatnia w tej części posiedzenia wystąpiła dr Urszula Tokarska (WSNS, Lublin) podejmując temat: Uniwersytet dla Rodziców i Dzieci - dla wspomagania kompetencji rodziców. Prelegentka starała się przybliżyć ideę Uniwersytetu dla Rodziców i Dzieci, którego głównym celem jest nie tylko podnoszenie kompetencji wychowawczych rodziców, ale scalenie i umocnienie więzi rodzinnych rodzice-dzieci, zwłaszcza przez wspólne zajęcia. Zajęcia na Uniwersytecie trwałyby cztery semestry, czyli dwa lata i odbywałyby się w soboty przed południem w systemie godzin lekcyjnych (45 minut) z przerwami na wspólne zabawy i zajęcia ruchowe. Doktor Tokarska zaprezentowała tematykę zajęć dla rodziców, dla dzieci oraz zajęć wspólnych. Proponowała także podjęcie studiów ze Wspomagania kompetencji rodziców i Familiologii.

Po zakończeniu wystąpienia rozpoczęła się dyskusja związana z prezentowanymi zagadnieniami dotyczącymi pracy. Po niej głos zabrał ks. prof. Marian Nowak podsumowując całe posiedzenie i dziękując za udział w zebraniu członkom ZPCh. Na koniec zaprosił wszystkich do udziału w Warsztatach w Kazimierzu Dolnym n. Wisłą w dniach 13-15 września tego roku na temat: Warsztat badawczy integralnego pedagoga pracy. Posiedzenie zakończyło się wspólnym obiadem w instytutowej kawiarni. 